Słomka-Gołębiowska A., Wptyw regulacji na wynagradzanie kadry zarzadzajacej instytucji fnansowych w Stanach Zjednoczonych, „Economics and Law”, Polszakiewicz B., Boehlke J. (ed.), Vol. 13, No. 1/2014, pp. 175-194. DOI: http://dx.doi.org/10.12775/EiP.2014.014.

\title{
WPŁYW REGULACJI NA WYNAGRADZANIE KADRY ZARZĄDZAJĄCEJ INSTYTUCJI FINANSOWYCH W STANACH ZJEDNOCZONYCH ${ }^{\diamond}$
}

\section{STRESZCZENIE}

Celem artykułu jest zaprezentowanie ścieżki zmian prawnych jako istotnego motoru ewolucji systemu wynagradzania kadry zarządzającej instytucjami finansowymi w Stanach Zjednoczonych. W szczególności zostanie sprawdzone, jak regulacje, w tym przepisy podatkowe, zasady księgowe, oraz obowiązki informacyjne spółek publicznych wpłynęły na praktyki wynagradzania kadry zarządzającej amerykańskich banków notowanych na giełdzie. Ścieżka zmian regulacyjnych odnoszących się do praktyk wynagradzania członków kadry zarządzającej w Stanach Zjednoczonych sprawiła, że ich uposażenia są od lat 90 . XX wieku najwyższe na świecie. Odpowiadał za to największy składnik wynagrodzenia - opcje na akcje, dla których najsilniejszym bodźcem do upowszechnienia się stało się połączenie zasad podatkowych, wedle których koszty programów opcyjnych odliczane były od podatku, i księgowych, nie zakładające żadnych wydatków na programy opcyjne. Dynamicznego wzrostu uposażenia kadry zarządzającej instytucjami finansowymi nie powstrzymało podnoszenie standardów ujawniania polityki wynagradzania, chętnie stosowanego przez władze legislacyjne oraz Komisję Papierów Wartościowych i Giełd (SEC). Regulacje, tworzone

"Agnieszka Słomka-Gołębiowska, Szkoła Główna Handlowa, Katedra Międzynarodowych Studiów Porównawczych, Al. Niepodległości 164, 02-554 Warszawa, tel.: +48 2256493 45, email: agnieszka.golebiowska@sgh.waw.pl.

Artykuł powstał dzięki finansowemu wsparciu badań naukowych przez Narodowe Centrum Nauki na mocy decyzji DEC-2011/03/B/HS4/04814. 
w dobrej wierze, wywołały szereg niezamierzonych i kosztownych efektów ubocznych. Charakter regulacji wprowadzonych w Stanach Zjednoczonych był raczej dyscyplinujący niż konstruktywny z uwagi na fakt, że były one inicjowane przez polityków, którzy kierują się polityczną agendą, a nie wartością dla akcjonariuszy czy interesariuszy banków.

Słowa kluczowe: ład korporacyjny, system wynagradzania kadry zarządzającej, banki, Stany Zjednoczone, ścieżka zależności od przeszłych zdarzeń

Klasyfikacja JEL: G01, G21, G34, G38

\section{THE IMPACT OF REGULATIONS ON EXECUTIVE COMPENSATION IN THE US FINANCIAL INSTITUTIONS}

\section{SUMMARY}

The purpose of this article is to present the path dependence of regulation as an important engine of evolution of executive compensation in the US financial institutions. In particular, the impact of regulations, including tax laws, accounting principles and disclosure requirements of public companies on the practice of rewarding executives of the US banks is examined. The regulatory changes contributed to the fact that executive compensations since 90s. are the highest in the world due to commonly used stock options that are the largest component of executive pay. Combining no accounting expense on the company's books, but a large deduction for tax purposes stock options virtually exploded. The dynamic rise of executive compensation was not halt by routinely expanded by SEC disclosure requirements. The regulations, developed in good faith, caused a number of unintended and costly side effects. The nature of regulation introduced in the United States was more disciplining than constructive due to the fact that they were initiated by politicians who are guided by a political agenda rather than the value for bank's shareholders and other stakeholders.

Keywords: corporate governance, executive compensation, banks, US, path dependency JEL Classification: G01, G21, G34, G38

\section{WSTĘP}

Amerykańskie praktyki ładu korporacyjnego są często traktowane jako główny punkt odniesienia dla reformatorów czy uczestników rynków finansowych w różnych krajach. Mimo to nie docenia się jego ewolucyjnego charakteru. A przecież ścieżka zależności od przeszłych zmian instytucjonalnych (path dependency) decyduje, jak rozwija się system ładu korporacyjnego. Od- 
powiada za różnice pomiędzy systemami ładu korporacyjnego różnych krajów, a co więcej implikuje, które jego mechanizmy mają zastosowanie w praktyce. Kształtuje oddolne wybory instytucjonalne, a w konsekwencji sprawa, że trudno zmienić kierunek przemian instytucjonalnych, kiedy jest się już na pewnej ścieżce. Wedle teorii zarysowanej przez L. Bebchuka i M. Roe'a ${ }^{1}$ ścieżkę zależności od przeszłych zmian dla ładu korporacyjnego wyznaczają z jednej strony jego cechy z najwcześniejszego etapu rozwoju, a drugiej strony uwarunkowania instytucjonalne, w szczególności prawne. Stany Zjednoczone należy zaliczyć do krajów, w których regulacje odgrywały i nadal odgrywają istotną rolę w kształtowaniu ładu korporacyjnego.

Przedmiotem analiz niniejszego opracowania jest jeden $\mathrm{z}$ mechanizmów ładu korporacyjnego - system wynagradzania kadry zarządzającej bankami w Stanach Zjednoczonych. Większość analiz poświęconych zagadnieniu wynagradzania kadry zarządzającej koncentruje się na jego efektywności w ograniczaniu problemu agencji, ignorując wpływ uwarunkowań instytucjonalnych. Celem opracowania jest zaprezentowanie ścieżki zmian prawnych jako istotnego motoru ewolucji systemu wynagradzania kadry zarządzającej instytucjami finansowymi w Stanach Zjednoczonych, który został wskazany jako jeden z głównych czynników odpowiedzialnych za wywołanie kryzysu finansowego w roku 2007 (OECD, 2009)². W szczególności, zostanie sprawdzone, czy dynamiczne zmiany wielkości oraz struktury wynagradzania kadry zarządzającej instytucjami finansowymi w Stanach Zjednoczonych były i są skutkiem wprowadzanych przepisów prawnych. Wśród nich można wyróżnić takie, które wprost ograniczają wielkość całkowitego uposażenia członków kadry zarządzającej banków lub poszczególnych jego składników. Drugą kategorię stanowią podatkowe przepisy prawne, standardy księgowe, obowiązki informacyjne spółki notowanej na giełdzie, których wprowadzenie może wywoływać zmiany systemu wynagradzania kierownictwa instytucji finansowych. Większość regulacji, które zostaną omówione w niniejszym opracowaniu nie odnosiła się wyłącznie do instytucji finansowych. Nie mniej jednak amerykańskie banki, które, w większości przypadków są spółkami publicznymi, były i są zobowiązane je przestrzegać.

Opracowanie, opatrzone wstępem, rozpoczyna się od omówienia głównych trendów w polityce wynagradzania kadry zarządzającej instytucjami fi-

${ }^{1}$ L. Bebchuk, M. Roe, Theory of Path Dependence in Corporate Ownership and Governance, [in:] J. Gordon, M. Roe (ed.), Convergence and Persistence in Corporate Governance, Cambridge University Press, Cambridge 2004, p. 69-113.

2 OECD, Corporate Governance and the Financial Crisis: Key Findings and Main Messages, Paryż, 2009. 
nansowymi w Stanach Zjednoczonych. W punkcie drugim omówiono przepisy prawne bezpośrednio odnoszące się do wielkości i struktury uposażenia kierownictwa banków w USA. W kolejnym punkcie omówiono wszelkie regulacje, które miały wpływ na praktykę wynagradzania kadry zarządzającej bankami. Opracowanie kończy się podsumowaniem.

\section{TRENDY W WYNAGRADZANIU KADRY ZARZĄDZAJĄCEJ W USA}

Do początku XX wieku większość amerykańskich firm była niewielka, a kierowaniem nimi zajmowali się ich właściciele. Dopiero wyłonienie się nowej profesji wyższej kadry zarządzającej wraz z upowszechnieniem się spółki akcyjnej, która umożliwiła zwiększenie firm do niespotykanych wcześniej rozmiarów, ujawniło potrzebę budowania dla nich systemów wynagradzania. Przypadło to w Stanach Zjednoczonych na okres zintensyfikowanych fuzji i przejęć z lat 1895-1904, kiedy z około 2000 firm przemysłowych powstało 157 korporacji. Zarządzanie nimi zostało zcentralizowane w rękach profesjonalnej kadry zarządzającej, której członkowie nie posiadali istotnych udziałów w spółkach. Pojawiła się zatem konieczność związania ich interesów z interesami akcjonariuszy. Włączono zatem nowy element wynagrodzenia - nagrodę roczną (bonus), którego wielkość miała być uzależniona od wyników spółki. Przy dość niepokaźnych wynagrodzeniach, w porównaniu do obecnych stawek, średnia wielkość bonusu wynosiła $42 \%$ całości uposażenia członka kadry zarządzającej w dwóch trzecich największych spółkach przemysłowych ${ }^{3}$.

Do lat 20. XX wieku wielkość nagrody rocznej, mimo szybkiego jej wzrostu w relacji do całości wynagrodzenia, w szczególności dla dyrektora generalnego (CEO), nie budziła większych zastrzeżeń opinii publicznej, w więc także polityków. Po części wynikało to $z$ braku informacji, gdyż nie było wówczas obowiązku ujawniania wielkości wynagrodzenia. $Z$ analiz przeprowadzonych przez C. Frydman i R. Saksa ${ }^{4}$ na danych o 50 największych spółach amerykańskich w latach 1936-2005 wynika, że wykres mediany wynagrodzenia trzech najlepiej opłacanych członków kadry zarządzającej ma kształt litery J. W czasie II Wojny Światowej zarobki kierownictwa spadły w stosunku do lat 30. XX wieku, i jeszcze bardziej się zmniejszyły w latach 40. XX wieku. Następnie do połowy lat 70. XX wieku pozostawały niemal na niezmienionym poziomie. Przeciętna roczna stopa wzrostu wynosiła $0.8 \%$. Dopiero od poło-

\footnotetext{
3 J. Baker, Executive Salaries and Bonus Plans, McGraw Hill, New York 1938, p. 64.

${ }^{4}$ C. Frydman, R.E Saks, Executive compensation: a new view from a long-term perspective 1936-2005, „Review of Financial Studies”, No. 23(5)/2010, p. 2099-2138.
} 
wy lat 70. obserwuje się dramatyczny wzrost uposażania kierownictwa dużych spółek aż do roku 2001, na który przypada największe tempo wzrostu.

Do lat 80. XX wieku wynagrodzenia kadry zarządzającej składały się niemal wyłącznie $z$ pensji zasadniczej i bonusu uzależnionego od rocznych wyników finansowych spółki. Pierwsza składowa uposażenia silnie była związana z wielkością przychodów spółki i raczej nie była wrażliwa na zmiany sytuacji finansowo-ekonomicznej spółki ${ }^{5}$. Badania empiryczne przeprowadzone przez B. Halla i J. Liebmana ${ }^{6}$ pokazują, że w roku 1980 większość rocznego wynagrodzenia dyrektora generalnego stanowiła pensja zasadnicza i bonus, czyli była rozliczeniem głównie gotówkowym.

C. Frydman i D. Jenter ${ }^{7}$ wyróżniają dwa wyraźne trendy w systemie wynagradzania kadry zarządzającej. Do połowy lat 70. XX wieku poziom uposażania był niski, podobny na różnych stanowiskach wyższej kadry zarządzającej, z nieznaczącym udziałem wynagrodzenia opartego o akcje spółki. Od połowy lat 70. wszystkie elementy wynagrodzenia, a więc pensja zasadnicza, bonus, długoterminowe programy motywacyjne oraz świadczenia dodatkowe, rosły bardzo szybko, podobnie jak różnice pomiędzy stanowiskami na poziomie wyższego kierownictwa, a także pomiędzy sektorami. Najlepiej wynagradzani stali się dyrektorzy wykonawczy dużych grup finansowych. Obecnie również znacząca cześć osób z grupy najwyżej zarabiających w Stanach Zjednoczonych jest zatrudniona w sektorze usług finansowych ${ }^{8}$.

Elementem wynagrodzenia kadry zarządzającej w Stanach Zjednoczonych, który wykazywał najszybsze tempo wzrostu było wynagrodzenie wypłacane w formie opcji na akcje. W roku 1994 opcje na akcje stały się największym komponentem wynagrodzenia wyższej kadry zarządzającej. 70\% dyrektorów otrzymywało już wynagrodzenie w formie opcji na akcje, których przeciętna wartość stanowiła 1,2 mln USD szacowanych metodą Blacka -Scholesa9. Dla porównania średnia wartość wynagrodzenia wypłacana w gotówce wynosiła 1,3 mln $\mathrm{USD}^{10}$. J. Core i W. Guay ${ }^{11}$ pokazują, że w okresie

${ }^{5}$ M. Jensen, K. Murphy, Remuneration: Where we've been, how we got to here, what are the problems, and how to fix them, ECGI Working Paper Series in Finance, 2004.

${ }^{6}$ B. Hall, J. Liebman, Are CEOs Really Paid Like Bureaucrats?, „Quarterly Journal of Economics", No. 113/1998, p. 653-691.

7 C. Frydman, D. Jenter, CEO Compensation, Sloan School of Management, Massachusetts Institute of Technology, 2010.

${ }^{8}$ B. Groom, Call to end 'corrosive' top pay deals, „Financial Times”, 22 listopada 2011.

${ }^{2}$ F. Black, M. Scholes, The Pricing of Options and Corporate Liabilities, "Journal of Political Economy", No. 81/1973, p. 637-654.

10 B. Hall, J. Liebman, op. cit.

${ }^{11} \mathrm{~J}$. Core, W. Guay, The Use of Equity Grants to Manage Optimal Equity Incentive Levels, „Journal of Accounting and Economics”, No. 28/1999, p. 151-184. 
1992-96 opcje stanowiły średnio około $1 / 3$ wartości portfela akcji będącego w rękach dyrektora generalnego oraz około połowy mediany wartości portfela akcji będącego w rękach dyrektora generalnego.

B. Hall i K. Murphy ${ }^{12}$ odnotowali, że już w roku 1998 mediana wartości wynagrodzenia wypłacana $\mathrm{w}$ akcjach dyrektorowi generalnemu spółek finansowych wchodzących w skład listy Standard \& Poor’s była wyższa niż w spółkach niefinansowych i wynosiła odpowiednio $30 \mathrm{mln}$ USD oraz $55 \mathrm{mln}$ USD.

Wzrost popularności opcji na akcje przyczynił się do gwałtowanego wzrostu wynagrodzeń kadry zarządzającej. M. Conyon i inni ${ }^{13}$ na próbie największych spółek publicznych wedle rankingu S\&P na danych za lata 1970-2009 pokazują, że wzrost płacy dyrektora generalnego od lat 70. XX wieku był wywołany przez wzrost udziału akcji lub jej pochodnych w całkowitym jego uposażeniu. Zaobserwowano istotne różnice pomiędzy dyrektorami generalnymi. Ci, którzy zarabiali najwięcej, ich uposażanie zwiększało się szybciej. Największe wynagrodzenie otrzymali dyrektorzy generalni w roku 2000. Średnie ich uposażenia w roku 1970 było 31 razy większe (mediana 26 razy) niż średnia płaca osoby zatrudnionej w sektorze produkcyjnym, natomiast w roku 2009 już 263 razy (mediana 219 razy).

Największy udział wynagrodzenia w formie akcji lub instrumentów pokrewnych w całości uposażenia został osiągnięty przez amerykańskie spółki publiczne w 1999 roku, na który przypadało najszybsze tempo rozwoju spółek informatycznych. W kolejnych latach spółki ograniczały wielkość akcji lub opcji na akcje wypłacane członkom kadry zarządzającej aż do roku 2005, kiedy udział wynagrodzenia opartego o papiery wartościowe spółki zaczął znowu rosnąć aż do 2008 roku. Znaczenie pozostałych elementów wynagrodzenia kadry zarządzającej zmarginalizowało się, gdyż ich udział nie był większy niż 5\% całości uposażenia. S. Balachandran i inni ${ }^{14}$ pokazują, że praktyki wynagradzania kadry zarządzającej w instytucjach finansowych i pozostałych sektorach podlegały konwergencji od końca lat $90 . \mathrm{XX}$ wieku.

Do dynamicznego wzrostu wynagrodzenia kadry zarządzającej od lat 80 . w Stanach Zjednoczonych przyczyniło się również wprowadzenie nowego instrumentu w systemie motywowania menedżerów określanego jako złote spa-

12 B. Hall, K. Murphy, The Trouble with Stock Options, „Journal of Economic Perspectives”, No. 17/2003, p. 49-70.

${ }^{13}$ M. Conyon, N. Fernandes, M. Ferreira, P. Matos, K. Murphy, The Executive Compensation Controversy: A Transatlantic Analysis, Fondazione Rodolfo De Benedetti, 2010.

${ }^{14}$ S. Balachandran, B. Kogut, H. Harnal, The Probability of Default, Excessive Risk, and Executive Compensation: A Study of Financial Services Firms from 1995 to 2008, Columbia Business School Research Paper, 2010. 
dochrony ( $z$ ang. golden prachute). Stanowiły one odprawę wypłacaną członkom kadry zarządzającej $\mathrm{w}$ razie niezawinionej przez nich utraty stanowiska.

K. Murphy i J. Zabojnik ${ }^{15}$, jak również S. Kaplan ${ }^{16}$ pokazują, że rosnąca popularność opcji w latach 1993-2001 załamała się i nastąpiło przerzucenie się w latach 2002-2009 na wynagrodzenie w formie akcji zastrzeżonych. W 2009 udział opcji na akcje spadł do poziomu 22\% wartości mediany całości wynagrodzenia dyrektora generalnego. Tymczasem wartość akcji zastrzeżonych stanowiła $31 \%$ wartości mediany całości wynagrodzenia.

Analiz poświęconych wyłączenie wynagrodzeniom kadry zarządzającej $\mathrm{w}$ instytucjach finansowych jest relatywnie niewiele. Jedna $\mathrm{z}$ pierwszych przeprowadzona przez J. Barro i J. Barro ${ }^{17}$ pokazuje, że zmiany w uposażeniu zależą on wyników banku mierzonych jako zwrot dla akcjonariuszy oraz zmiany kursu akcji banku. J. Houston i Ch. James ${ }^{18}$ dokumentują w oparciu o dane za lata 1980-1990 o 134 bankach, że przeciętnie dyrektorzy generalni instytucji finansowych otrzymują mniej wynagrodzenia w gotówce, mają mniejsze prawdopodobieństwo udziału w programie opcyjnym, utrzymują mniej opcji na akcje oraz ich wynagrodzenia są w mniejszym stopniu oparte o akcje banku w porównaniu ze spółkami niefinansowymi. J. Ang i inni ${ }^{19}$ wskazują na podstawie danych za lata 1993-1996 o 166 amerykańskich bankach, że struktura wynagrodzenia dyrektora generalnego różni się od struktury wynagrodzenia innych członków kierownictwa, ponieważ ci pierwsi zarabiają więcej i otrzymują większe wynagrodzenie oparte na akcjach niż ci drudzy. R. Adams i H. Mehran ${ }^{20}$ pokazują na przykładzie danych o 35 holdingach bankowych, że zależność pomiędzy wynikami banku a wynagrodzeniem kadry zarządzającej jest słabsza niż w dużych korporacjach niefinansowych. T. Philippon i A. Reshef ${ }^{11}$ potwierdzają ogólny trend, że kierownictwo

${ }^{15}$ K. Murphy, J. Zábojník, CEO pay and appointments: a market-based explanation for recent trends, „American Economic Review”, No. 94(2)/2004, p. 192-196.

16 S. Kaplan, Executive Compensation and Corporate Governance in the U.S.: Perceptions, Facts and Challenges, mimeo, 2012.

17 J.R. Barro, J.R. Barro, Pay, Performance, and Turnover of Bank CEOs, "Journal of Labor Economics", No. 8(4)/1990, p. 448-481.

$18 \mathrm{~J}$. Houston, Ch. James, CEO compensation and bank risk: is compensation in banking structured to promote risk taking, "Journal of Monetary Economics”, No. 36/1995, p. 405-431.

19 J. Ang, S. Hauser, B. Lauterbach, Top Executive Compensation under Alternative Ownership and Governance Structures, „Advances in Financial Economics”, No. 3/1997, p. 1-32.

${ }^{20}$ R. Adams, H. Mehran, Is Corporate Governance Different for Bank Holding Companies?, Federal Reserve Bank of New York Staff Reports, No. 539/2003.

${ }_{21}$ T. Philippon, A. Reshef, Wages and Human Capital in the U.S. Financial Industry: 1909-2006, NBER Working Paper, No. 14644/2009. 
banków w USA otrzymywało nadmiernie wysokie wynagrodzenia w okresie 1990-2006.

\section{REGULACJE WYNAGRADZANIA KADRY ZARZĄDZAJĄCEJ BANKAMI}

Istotnym wydarzeniem, mającym wpływ na wprowadzenie pierwszych regulacji odnoszących się do wynagrodzenia kadry zarządzającej dużymi spółkami, była historia wykupu kontrolowanego przez państwo spółki RFC. W roku 1932 Interstate Commerce Commission domagała się ujawnienia uposażania wszystkich członków kadry zarządzającej RFC, zarabiających powyżej 10,000 USD rocznie. Ujawnione wielkości wynagrodzenia zgorszyły opinie publiczną i nową administrację prezydenta F. D. Roosevelta. Dlatego w maju 1933 wprowadzono nakaz ograniczenia uposażenia do 60\% dla tych zarabiających więcej niż 100,000 USD rocznie i 15\% dla tych zarabiających 15,000 USD rocznie. Limity wielkości wynagrodzenia dotyczyły kadry zarządzającej spółkami starającymi się o pożyczki od państwa ${ }^{22}$.

$\mathrm{Na}$ kolejny przepis prawny bezpośrednio odnoszący się do wynagrodzenia kadry zarządzającej w Stanach Zjednoczonych trzeba było czekać bardzo długo. Dopiero w odpowiedzi na kryzys finansowy z lat 2007-2008, porównywany niejednokrotnie $\mathrm{z}$ kryzysem gospodarczym $\mathrm{z}$ lat 30 . XX wieku, wprowadzono nowe regulacje. 21 lipca 2010 weszła w życie Ustawa Wall Street Reform and Consumer Protection Act określana jako Ustawa Dodda-Franka.

Ustawa Dodda-Franka poświęca sporo miejsca polityce wynagradzania kadry zarządzającej instytucjami finansowymi. Przepis 951 nadaje uprawnienia akcjonariuszom spółki publicznej, umożliwiając im wydawanie opinii na ten temat przynajmniej raz na trzy lata (ang. say on pay). Ale charakter uchwały walnego zgromadzenia akcjonariuszy nie jest wiążący dla spółki. Ponadto, spółki muszą ujawniać oraz przekazać pod głosowanie akcjonariuszy wysokość odpraw, które zostały uzgodnione w związku z transakcjami przejęć, procedurami przetargowymi czy transakcjami wyjścia $z$ giełdy.

Przepis 954 nakazuje wprowadzenie i raportowanie wydarzeń związanych ze zwrotem części lub całości bonusu w wyniku zmaterializowania się pewnych ryzyk i w konsekwencji, ujawnienia się potrzeby istotnych księgowych dostosowań. Uprzednio, wedle Ustawy Sarbanes-Oxley (SOX), zasada ta od-

${ }^{22}$ K. Murphy, Executive Compensation: Where We Are, and How We Got There, [in:] G. Constantinides, M. Harris, R. Stulz (ed.), Handbook of the Economics of Finance, Elsevier Science North Holland 2012. 
nosiła się wyłącznie do dyrektora generalnego (CEO) i członka zarządu ds. finansowych (CFO). Nowe przepisy objęły wszystkich dyrektorów wykonawczych oraz rozszerzyły horyzont czasowy z 12 miesięcy do trzech lat, w ciagu których ryzyka mogą się zmaterializować. Bardzo rzadko podejmowano próby odzyskania mylnie przyznanych nagród rocznych, uzasadniając to wysokimi kosztami prowadzenia spraw sądowych oraz niewielkimi możliwościami odzyskania środków pieniężnych wypłaconych i opodatkowanych. Nowe zapisy Ustawy Dodda-Franka nakładają na radę dyrektorów odpowiedzialność podjęcia się tego trudu, a w razie niewywiązania się przez nią $\mathrm{z}$ tego obowiązku, występuje groźba pozwu sądowego złożonego przez akcjonariuszy.

Wedle przepisów 953, 955, 972 Ustawy Dodda-Franka spółki publiczne muszą raportować, jaki jest stosunek wynagrodzenia dyrektora generalnego do mediany płacy wszystkich pracowników. Ponadto powinny analizować związek pomiędzy wynagrodzeniem kierownictwa i wynikami finansowymi spółki, oraz publikować rezultaty analiz. Wskazuje się również, że polityka zabezpieczenia się spółki przed spadkiem cen jej akcji powinna być udostępniana wszystkim interesariuszom. Wreszcie, spółki muszą wyjaśnić, jaką politykę i praktyki stosują w zakresie oddzielenia funkcji dyrektora generalnego i przewodniczącego rady dyrektorów.

Nowa regulacja aktywizuje również akcjonariuszy, umożliwiając im nominowanie swoich kandydatów na stanowisko członka rady w ramach procedury proxy statement oraz nawiązuje do istotnej problematyki niezależności komitetu rady ds. wynagrodzeń. Wymagania te nie były nowością dla dużych korporacji, które już od 2003 roku są zobowiązane powołać komitet rady ds. wynagrodzeń, składający się wyłącznie z niezależnych członków zgodnie $z$ regulaminem giełdy w Nowym Yorku (NYSE oraz NASDAQ). Jeszcze wcześniej Urząd Skarbowy w Stanach Zjednoczonych zawarł w swoich przepisach prawnych $162 \mathrm{~m}$ normę obowiązującą już od roku 1994, która nakazywała utrzymanie niezależności komitetu rady ds. wynagrodzeń.

Ustawa Dodda-Franka wymusiła największe od czasu wprowadzenia w 1934 Security Act reformy dotyczące systemu wynagrodzeń kadry zarządzającej i ładu korporacyjnego. Zakres zmian prawnych istotnie zmienił środowisko regulacyjne dla sektora bankowego. Część norm dotyczących ładu korporacyjnego $\mathrm{w}$ zakresie procesu określania wynagrodzenia dla kadry zarządzającej, odniesiono do wszystkich spółek publicznych, nie tylko instytucji finansowych. Normy zawarte w ustawie Dodda-Franka zaczęły obowiązywać od razu spółki o wysokiej kapitalizacji przekraczającej $75 \mathrm{mln}$ USD, a pozostałym zagwarantowano trzy lata na dostosowanie. 


\section{POŚREDNI WPŁYW REGULACJI}

\subsection{PRZEPISY PODATKOWE}

Przepisy podatkowe w Stanach Zjednoczonych odegrały ważną rolę w kształtowaniu struktury wynagrodzenia kadry zarządzającej, a w mniejszym stopniu wpłynęły na jego poziom. Szczególnie istotne znaczenie miały dla wzrostu popularności opcji na akcje. Mimo że opcje na akcje pojawiły się w Stanach Zjednoczonych niemal równocześnie jak podatek dochodowy od osób fizycznych, kwestie podatkowe wokół nich nie zostały jednoznacznie uregulowane przez ponad 20 lat. W przepisach prawnych nie było jasnej normy, jak powinny być opodatkowane. Jednym z rozwiązań było traktowanie ich jako wynagrodzenia w momencie realizacji opcji, a przez to stanowiły dochód osoby fizycznej i wydatek spółki wliczany w koszty operacyjne. Za takim rozwiązaniem optował Urząd Skarbowy. Alternatywne podejście zakładało, że dopiero sprzedaż akcji ze zrealizowanych opcji rodzi obowiązek odprowadzenia podatku. W tym przypadku dochód dla poszczególnych członków kadry zarządzającej byłby opodatkowany wedle niższej stopy podatku od zysków kapitałowych.

Po 20 latach procesu sądowego Sąd Najwyższy w USA wydał w roku 1945 orzeczenie przychylające się do stanowiska Urzędu Skarbowego. Decyzja ta, w połączeniu ze zwiększeniem stawek podatku dochodowego, przyczyniła się na koniec lat 40. XX wieku do ograniczenia stosowania programów opcyjnych. Stały się one nieopłacalne ze względu na wprowadzone najwyższe stawki podatku dochodowego od osób fizycznych i prawnych, które wzrosły odpowiednio do $91 \%$ i do $42 \%$ z $25 \%$ i $12 \%$ - stawki obowiązujące w roku 1928. W tym czasie stopa podatku od zysku kapitałowego wynosiła $25 \%$ i wzrosła w porównaniu z rokiem 1920 o 12,5 punktów procentowych. W dodatku, Sąd Najwyższy wydał orzeczenie, w którym nakazywał uiszczenie podatku dochodowego niezwłocznie po zrealizowaniu opcji na akcje. Wkrótce potem regulacje rynku kapitałowego z roku 1934 (Securities Act) zobowiązywały członków kadry zarządzającej do utrzymywania akcji z programów opcyjnych przynajmniej przez okres sześciu miesięcy. W konsekwencji, popularność opcji na akcje jeszcze bardziej spadła ${ }^{23}$.

W celu zrekompensowania utraty ważnego elementu systemu motywacyjnego kadry zarządzającej przychylny biznesowi Senat wydał w roku 1950

${ }^{23}$ Ibidem. 
przepis stwarzający nowy instrument wynagradzania - akcje zastrzeżone $\left(R e^{-}\right.$ stricted stock option). Zostały one preferencyjne opodatkowane, niższą stawką podatku od zysków kapitałowych, którą należało uiścić tylko w przypadku sprzedaży akcji. W efekcie, stały się dominującym elementem wynagrodzenia menedżerów aż do początku lat 60 . XX wieku, kiedy ujawniono liczne uchybienia $\mathrm{w}$ korzystaniu $\mathrm{z}$ nich. Zmiany podatkowych przepisów prawnych w roku 1964 znacząco ograniczały korzyści z nich płynące. Wprowadzono obowiązek utrzymania akcji przez co najmniej trzy lata i stworzenie programu opcyjnego na co najwyżej pięć lat, zabraniając zbycia akcji, jeśli członek kierownictwa nabył opcje na akcje wcześniej ${ }^{24}$. Wreszcie, zmniejszono najwyższą stawkę krańcowej stopy podatku dochodowego z 90\% do 77\%. Trend obniżania podatków był kontynuowany przez kolejne lata. W roku 1969 ustawa o reformie podatkowej jeszcze bardziej obniżyła stawkę krańcowej stopy podatku dochodowego z $77 \%$ do $50 \%$. Nowe przepisy prawne zmniejszyły również stawkę podatku dochodowego od osób prawnych (CIT) z 52,8\% do 48\%, jednocześnie zwiększając górną stawkę podatku od zysków kapitałowych z 25\% w 1969 roku do 36,5\% w $1972^{25}$.

Wprowadzone zmiany przepisów podatkowych obniżyły istotnie koszty zwykłych programów opcyjnych w porównaniu $\mathrm{z}$ akcjami zastrzeżonymi. Jednak te pierwsze nie od razu zyskały na popularności jako instrument wynagradzania kadry zarządzającej ze względu na ciągle obowiązujące przepisy prawne utrzymywania akcji po zrealizowaniu opcji przez co najmniej 6 miesięcy. W roku 1976 Komisja Papierów Wartościowych i Giełd (SEC) umożliwiła ominięcie tej zasady poprzez nadanie Stock Appreciation Rights. Uprawnienia te pozwalały na wypłatę ekwiwalentu gotówkowego wartości otrzymanych opcji. Wiele spółek zdecydowało się na to rozwiązanie.

W tym okresie wzrosło również znaczenie innego składnika wynagrodzenia kadry zarządzającej, które określane jest jako jego pochodna - odprawy. W Ustawie Deficit Reduction Act z roku 1984 przepis 280 G nakładał surowe kary na członka kadry zarządzającej, jak i na spółkę, jeśli odprawa przekraczała trzykrotność przeciętnego aktualnego wynagrodzenia. Wbrew oczekiwaniom niniejsza regulacja nie przyczyniła się do zmniejszenia wielkość odpraw. Po pierwsze, określenie limitu spowodowało, że większość spółek publicznych, które dotychczas nie przewidywało odpraw dla członków kadry zarządzającej wprowadziła je. Po drugie, nastąpiło zwiększenie przeciętnego uposażenia członka kadry zarządzającej, zachęcając do realizacji opcji wcześniej niż po-

${ }^{24}$ W. Lewellen, Executive Compensation in Large Industrial Companies, National Bureau of Economic Research, New York 1968.

${ }^{25}$ K. Murphy, op. cit. 
przednio. Wreszcie, nowe przepisy prawne przyczynity się do stosowania na masową skalę umowy o pracę z członkami kadry zarządzającej, wpisując w nią zapis o odszkodowaniu za rozwiązanie umowy bez względu na powód, a nie jak było wcześniej tylko w wypadku zmiany praw do kontroli nad spółką.

Dopiero lata 90. XX wieku przyniosły eksplozję opcji na akcje. M. Conyon i inni ${ }^{26}$ wymieniają trzy zasadnicze czynniki, które przyczyniły się do zwiększania ich popularności w polityce wynagradzania kadry zarządzającej: większe zaangażowanie akcjonariuszy w ład korporacyjny i ich naciski na większe związanie uposażenia kadry zarządzającej ze wzrostem stopy zwrotu $\mathrm{z}$ ich inwestycji, wprowadzenie bardziej przejrzystych zasad księgowego traktowania opcji na akcje, oraz kolejna zmiana przepisów podatkowych.

Ostatni z wymienionych czynników odnosił się do wprowadzenia ograniczenia wielkości wydatków na wynagrodzenia dla kadry zarządzającej, które odliczane są od podstawy do opodatkowania. W roku 1992 prezydent Clinton zrealizował swoją obietnicę wyborczą i zmienił prawo podatkowe, zabraniając odpisywania wydatków spółki na wynagrodzenia kadry zarządzającej wyższych niż $1 \mathrm{mln}$ USD. Przepis ten odnosi się do pięciu najlepiej opłacanych członków kadry zarządzającej, w tym dyrektora generalnego. Norma ta nie objęła wszelkich elementów uposażenia, a jedynie te, które nie były związane $\mathrm{z}$ wynikami spółki, czyli płacę zasadniczą, akcje ograniczone oraz świadczenia dodatkowe.

$\mathrm{Z}$ perspektywy podatkowej programy opcyjne są nadal atrakcyjnym instrumentem motywowania kadry zarządzającej, jako że są obciążone niższym podatkiem od zysków kapitałowych. Trend obniżania tej stawki podatkowej utrzymał się w latach 90 . XX wieku, gdy wynosiła ona $28 \%$ i osiągnęła wielkość 15\% w roku 2003, przy czym dla osób najmniej zarabiający - 5\%. Niska stawka podatkowa utrzymała się aż do roku 2012.

\subsection{ZASADY KSIĘGOWE}

Zasady księgowe odnoszące się do poszczególnych składników wynagrodzenia nie budziły poważnych zastrzeżeń regulatorów, polityków czy opinii publicznej, poza tymi odnoszącymi się do programów opcyjnych. Do lat 70. XX wieku opcje na akcje nie były traktowane w świetle przepisów prawa podatkowego jako wynagrodzenie kadry zarządzającej. Sytuację zmieniła reforma prawa podatkowego z roku 1969, która wywołało dyskusje o potrzebie ich ujęcia w sprawozdaniu finansowym spółki.

${ }^{26}$ M. Conyon, N. Fernandes, M. Ferreira, P. Matos, K. Murphy, op. cit. 
W 1972 roku Accounting Principle Board, której następcą została Financial Accouting Standards Board - FASB wydała opinie numer $35 \mathrm{w}$ sprawie księgowych zasad raportowania akcji wydanych pracownikom. Wedle niej wydatki na wynagrodzenia dla kadry zarządzającej w formie opcji na akcje zostały zdefiniowane jako różnica pomiędzy rynkową ceną akcji w dniu przyznania opcji a ceną realizacji opcji. Wartość ta była amortyzowana przez okres, w którym dyrektor nie może zrealizować opcji. Wedle tej zasady programy opcyjne nie obciążały wydatków spółki, jeśli cena realizacji opcji była większa niż kurs akcji w dniu przyznania opcji.

Dopiero połowa lat 90. XX wieku przyniosła zwrot w polityce sprawozdawczości finansowej stosowanej wobec opcji na akcje. FASB ogłosiła plany wprowadzenia nowych zasad rachunkowości, wedle których spółka musiałaby zaksięgować koszty programów opcyjnych, przyjmując rynkową cenę akcji $\mathrm{w}$ dniu przyznania opcji. Jednak pod wpływem lobby firm audytowych oraz spółek notowanych na giełdzie, zwłaszcza $z$ sektora high-tech, przewidujących, że zmniejszyłoby to konkurencyjność młodych amerykańskich spółek technologicznych, FASB zarzuciła pomysł. Wydała jedynie rekomendacje, aby przekazane opcje były odzwierciedlone w raporcie rocznym w wartości godziwej, wykorzystując np. metodologię Blacka-Scholesa. Zaproponowano również ujawnianie wartości programów opcyjnych na dzień ich przyznania w notach do sprawozdania finansowego.

Połączenie zasad podatkowych, wedle których koszty programów opcyjnych odliczane były od podatku, i księgowych, nie zakładające żadnych wydatków na programy opcyjne rozliczane w bilansie spółki, stanowiło najsilniejszy bodziec do upowszechnienie się opcji na akcje, dzięki czemu stały się największym elementem wynagrodzenia menedżerów amerykańskich spółek publicznych. Dopiero seria skandali korporacyjnych w latach 2001-2002 zmieniła sytuację. W roku 2002 Kongres Amerykański uchwali Ustawę SOX, która wprowadziła m.in. pewne uregulowania w zakresie wynagrodzeń kadry zarządzającej. Przepis 402 SOX zabrania udzielania kierownictwu spółki pożyczek, najczęściej wykorzystywanych na zakup akcji spółki. Nie zezwala również na bezgotówkowe programy opcyjne, w ramach których dyrektor wykonawczy, realizując opcje na akcje, wykorzystywał akcje do rozliczenia podatku związanego $z$ realizacją opcji.

Duże zasługi wniosła nowa Ustawa SOX dla wyeliminować nieuczciwego antydatowania opcji, dzięki włączeniu przepisu 403, który wymagał od dyrektorów ujawnienia programów opcyjnych w ciągu 2 dni od dnia przyznania opcji. Wcześniej było to przynajmniej 45 dni od zamknięcia roku podatkowego. Umożliwiało to falsyfikację umowy o programie opcyjnym tak, aby ujawnić cenę przekazania opcji na dzień, kiedy była ona najniższa. 
Po raz pierwszy, pojawił się przepis - 304, który przewidywał stosowanie instrumentów warunkowego wypłacenia wynagrodzenia. Oznacza to, że może pojawić się konieczność oddania części wypłaconego już wynagrodzenia (clawbacks) przez dyrektora generalnego (CEO) lub dyrektora ds. finansowych (CFO), jeśli będzie trzeba dokonać zmian w sprawozdaniu finansowym. Mimo wielu przypadków zafałszowań rachunkowych przepis nie był skutecznie egzekwowalny aż do kryzysu finansowego z roku 2008.

\subsection{OBOWIĄZKI INFORMACYJNE}

Przepisy określające zakres obowiązków informacyjnych dotyczących systemu wynagradzania kadry zarządzającej pojawiały się po raz pierwszy w okresie kryzysu gospodarczego z lat 30. Na początku XX wieku Rezerwa Federalna rozpoczęła dochodzenie $\mathrm{w}$ sprawie poziomu wynagrodzeń kadry zarządzającej bankami w Stanach Zjednoczonych. Jednym z jego skutków było przyjęcie w roku 1933 przez nadzór bankowy norm prawnych opracowanych przez Federal Trade Commission, które nakazywały wszystkim korporacjom, których wielkość aktywów była większa niż $1 \mathrm{mln}$ USD, ujawnianie pensji zasadniczej i bonusu członków kadry zarządzającej. Obowiązek upublicznienia wynagrodzeń wyższego kierownictwa spółek publicznych został włączony również do przepisów prawnych regulujących działalność rynku kapitałowego Securities Act z roku 1933, a ich egzekwowaniem zajęła się nowoutworzona Komisji Papierów Wartościowych i Giełd - SEC. W grudniu 1934 roku SEC opublikował zasady ujawniania przez spółki giełdowe indywidualnych wynagrodzeń trzech najlepiej opłacanych członków kadry zarządzającej w rozbiciu na płacę zasadniczą, nagrodę roczną, akcje i opcje na akcje. Spółki, które nie dostosowały się do nowych zasad do czerwca 1935 zostały wyłączone z obrotu giełdowego. Do dziś wynagrodzenia są ujawniane w dokumentacji (proxy statement) przekazywanej akcjonariuszom przed zwyczajnym walnym zgromadzeniem, przyjmującym roczne sprawozdanie. Objętość tego dokumentu początkowo sięgała kilku stron, przy czym wynagrodzeniom kadry zarządzającej poświęcona była zazwyczaj nie więcej niż jedna strona. W roku 2007 dokument ten miał już około 70 stron, z czego większość dotyczyła systemu wynagradzania kadry zarządzającej ${ }^{27}$.

Jeden $\mathrm{z}$ najistotniejszych obowiązków informacyjnych, jakie wprowadziła SEC w zakresie ujawniania polityki wynagradzania kadry zarządzającej, odnosił się do świadczeń dodatkowych. Ich znaczenie wzrosło jako efekt kompensacyjny spadku udziału programów opcyjnych w całości uposażenia kadry

${ }^{27}$ K. Murphy, op. cit., p. 46. 
zarządzającej. Wielkość korzyści dodatkowych nie jest związana z wynikami spółki. Zalicza się do nich niskooprocentowane pożyczki dla członków kadry zarządzającej, możliwość korzystania z służbowych jachtów, samolotów czy samochodów, czy członkostwo w prestiżowych klubach biznesowych. Ich rosnący udział w całości uposażania członka kadry zarządzającej w latach 70. XX wieku wzbudził zainteresowanie akcjonariuszy, w szczególności inwestorów instytucjonalnych, którzy, wcześniej pasywni, rozpoczęli angażować się w nadzór nad spółką. Wysokie świadczenia dodatkowe przykuły również uwagę Urzędu Skarbowego z racji ich niepodatkowego charakteru oraz regulatora - SEC. Obie instytucje podjęły inicjatywy ich ograniczenia. SEC wprowadziła w roku 1977 i później w roku 1978 obowiązek rozległego ujawniania wielkości wszystkich świadczeń dodatkowych bez względu czy zostały wypłacone w pieniądzu czy w innej formie. W roku 1979 reguła ta została jeszcze bardziej dopracowana i wskazywała, że wszelkie formy wynagrodzenia, przekraczające sumę 10,000 USD rocznie muszą zostać ujawnione i szczegółowo opisane ${ }^{28}$. Dodatkowo, od roku 1993 zobowiązano spółki do podzielenia się z akcjonariuszami informacjami, czy spółka udziela opcji po cenie innej niż godziwa cena rynkowa.

Kolejne zasady ujawniania informacji o programie opcyjnym wprowadzono w roku 2006, aby zidentyfikować przypadki antydatowania opcji. Spółki musiały przekazać informacje o czasie trwania programu opcyjnego, cenie realizacji transakcji, dacie wygaśnięcia programu, dacie przyznania opcji oraz szacunkowej wartości przyznanych opcji, a także ilości i rodzaju akcji będących w posianiu poszczególnych członków kadry zarządzającej wedle stanu na koniec roku. Nowe regulacje rozszerzyły także liczbę osób do pięciu najlepiej opłacanych członków wyższej kadry zarządzającej, dla których spółka powinna ujawniać wszystkie komponenty pakietu wynagrodzenia.

Jednym z najtrudniejszych zadań, jakie stanęło przed SEC od czasu kryzysu gospodarczego $\mathrm{z}$ lat 30 . XX wieku, było zaimplementowanie określonych zapisów Ustawy Dodda-Franka, odnoszących się do polityki wynagrodzeń kadry zarządzającej instytucji finansowych. W 2011 roku SEC wraz z siedmioma innymi organizacjami rządowymi podjęła wysiłek uszczegółowienia zapisu 956 Ustawy Dodda-Franka dotyczącego nadmiernych wynagrodzeń kadry zarządzającej bankami. Zobligowano banki do wytypowanie członków kierownictwa czy innych pracowników, które mogą narazić je na istotne ryzyko i rozłożenie wypłaty uposażenia w czasie tak, że przynajmniej 50\% ich bonusu było wypłacane w ciągu przynajmniej trzech lat. 
Przepis 951 (say on pay) został zaimplementowany przez SEC w 2011 roku. Zagadnienia związane $\mathrm{z}$ niezależnością komitetu ds. wynagrodzeń zostały wprowadzone w życie w czerwcu 2011, a rozszerzone obowiązki informacyjne 18 września 2013 roku. Trwają prace SEC nad wdrożeniem przepisów Ustawy Dodda-Franka o warunkowym wypłacaniu wynagrodzenia (clawback) oraz możliwości nominowania przez akcjonariuszy członków rady dyrektorów. Ostatnie zagadnienie budzi największy sprzeciw kadry zarządzającej spółek, a zaproponowane przez SEC przepisy zostały zaskarżone przez menedżerską organizację lobbingową Business Roundtable oraz US Chamber of Commerce.

$\mathrm{Z}$ powyższych analiz instytucjonalnych wynika, że najchętniej wykorzystywaną metodą władz legislacyjnych (Kongresu) oraz SEC ograniczania wynagrodzeń kadry zarządzającej postrzeganych, jako nadmierne, było podnoszenie standardów ujawniania. Transparentność polityki wynagradzania nawiązywała do nieformalnych instytucji takich jak: reputacja i kontrola społeczna. Zasada „nazwanie rzeczy po imieniu i zawstydzenie” - name and shame - miała przyczyniać się do bardziej powściągliwych praktyk ustanawiania wielkości wynagrodzeń. W szczególności, ostatnie dwie dekady upłynęły pod hasłem zwiększania transparentności systemu wynagradzania kadry zarządzającej dużych korporacji, jak również większej niezależności komitetu ds. wynagrodzeń odpowiedzialnego za określanie struktury i poziomu wynagrodzenia.

\section{ZAKOŃCZENIE}

System wynagradzania kadry zarządzającej instytucji finansowych w Stanach Zjednoczonych zmieniał się na przestrzeni ostatnich stu lat, dostosowując się do wymogów prawnych takich jak: przepisów podatkowych, zasad rachunkowości czy obowiązków informacyjnych spółek publicznych. Kierunki zmian zależały od wprowadzanych przez amerykański rząd regulacji, które były inicjowane y przez polityków w odpowiedzi na faktyczne lub domniemane nadużycia w wynagradzaniu menedżerów (przypadek spółki Enron czy kryzys finansowy z lat 2007-2008). Stąd też istotna rola klimatu politycznego i ogólnej kondycji gospodarki w określaniu poziomu i struktury uposażenia kierownictwa wyższego szczebla ${ }^{29}$.

Ścieżka zmian regulacyjnych odnoszących się do praktyk wynagradzania członków kadry zarządzającej w Stanach Zjednoczonych sprawiła, że ich upo-

${ }^{29}$ M. Bertrand, S. Mullainathan, Are CEOs Rewarded for Luck? The Ones without Principles Are, „Quarterly Journal of Economics”, No. 116(3)/2001 oraz L. Bebchuk, J. Fried, Pay without performance: Overview of the issues, „Academy of Management Perspective”, No. 20(5-24)/2006. 
sażenia są od lat 90. XX wieku najwyższe na świecie. Odpowiadał za to największy składnik wynagrodzenia - opcje na akcje, dla których najsilniejszym bodźcem do upowszechnienia się było połączenie zasad podatkowych, wedle których koszty programów opcyjnych odliczane były od podatku, i księgowych, nie zakładające żadnych wydatków na programy opcyjne. Dynamicznego wzrostu uposażenia kadry zarządzającej instytucji finansowych nie powstrzymało podnoszenie standardów ujawniania polityki wynagradzania, chętnie stosowane przez SEC oraz władze legislacyjne.

Regulacje, tworzone w dobrej wierze, wywołały szereg niezamierzonych i najczęściej kosztownych efektów ubocznych. Przykładem interwencji państwa $\mathrm{w}$ formie regulacji, których cel jest uzasadniony ekonomicznie, ale ma efekty uboczne, są przepisy podatkowe ograniczające stały element wynagrodzenia do kwoty $1 \mathrm{mln}$ USD, co dramatycznie zwiększyło udział opcji na akcje, a przez to wywołało bardzo szybkie tempo wzrostu całkowitego uposażenia amerykańskiej kadry zarządzającej we wszystkich spółkach, nie tylko w instytucjach finansowych. Podobnie, przepisy wprowadzone po kryzysie finansowym z lat 2007-2008 odraczające w czasie wypłatę części zmiennych składników przyczyniły się do zwiększenia pensji zasadniczej dyrektorów wykonawczych instytucji finansowych ${ }^{30}$.

Generalnie, charakter amerykańskich regulacji był raczej dyscyplinujący niż konstruktywny z uwagi na fakt, że były inicjowane przez polityków, którzy kierują się polityczną agendą, a nie wartością dla akcjonariuszy czy interesariuszy banków. Konkludując, należy zauważyć, że wprowadzanie regulacji, bazujących na amerykańskich doświadczeniach w krajach o innej ścieżce zmian prawnych może mieć odwrotny do zakładanego skutek ekonomiczny, przyczyniając się do pogłębienia problemów wynagradzania kadry zarządzającej bankami, a nie do ich rozwiązania.

\section{BIBLIOGRAFIA}

Adams R., Mehran H., Is Corporate Governance Different for Bank Holding Companies?, Federal Reserve Bank of New York Staff Reports, No. 539/2003, http:// dx.doi.org/10.2139/ssrn.387561.

Ang J., Hauser S., Lauterbach B., Top Executive Compensation under Alternative Ownership and Governance Structures, „Advances in Financial Economics”, No. 3/1997.

${ }^{30}$ K. Murphy, op. cit. oraz A. Słomka-Gołębiowska, Uniform regulation of executive pay at banks: Will it make a difference? The case study of Poland, „International Journal of Disclosure and Governance", No. 10(2)/2013, p. 135-154. 
Baker J., Executive Salaries and Bonus Plans, McGraw Hill, New York 1938.

Balachandran S., Kogut B., Harnal H., The Probability of Default, Excessive Risk, and Executive Compensation: A Study of Financial Services Firms from 1995 to 2008, Columbia Business School Research Paper, 2010.

Barro J.R., Barro J.R., Pay, Performance, and Turnover of Bank CEOs, ,Journal of Labor Economics",No. 8(4)/1990, http://dx.doi.org/10.1086/298230.

Bebchuk L., Fried J., Pay without performance: Overview of the issues, „Academy of Management Perspective", No. 20(5-24)/2006, http://dx.doi.org/10.5465/ amp.2006.19873407.

Bebchuk L., Roe M., Theory of Path Dependence in Corporate Ownership and Governance, [in:] J. Gordon, M. Roe (ed.), Convergence and Persistence in Corporate Governance, Cambridge University Press, Cambridge 2004.

Bertrand M., Mullainathan S., Are CEOs Rewarded for Luck? The Ones without Principles Are, „Quarterly Journal of Economics”, No. 116(3)/2001, http://dx.doi. org/10.1162/00335530152466269.

Black F., Scholes M., The Pricing of Options and Corporate Liabilities, „Journal of Political Economy", No. 81/1973, http://dx.doi.org/10.1086/260062.

Conyon M., Fernandes N., Ferreira M., Matos P., Murphy K., The Executive Compensation Controversy: A Transatlantic Analysis, Fondazione Rodolfo De Benedetti, 2010.

Core J., Guay W., The Use of Equity Grants to Manage Optimal Equity Incentive Levels, „Journal of Accounting and Economics”, No. 28/1999, http://dx.doi.org/10.1016/ s0165-4101(99)00019-1.

Frydman C., Jenter D., CEO Compensation, Sloan School of Management, Massachusetts Institute of Technology, 2010.

Frydman C., Saks R.E, Executive compensation: a new view from a long-term perspective 1936-2005, „Review of Financial Studies”, No. 23(5)/2010, http://dx.doi. org/10.1093/rfs/hhp120.

Groom B., Call to end 'corrosive' top pay deals, „Financial Times”, 22 listopada 2011.

Hall B., Liebman J., Are CEOs Really Paid Like Bureaucrats?, "Quarterly Journal of Economics", No. 113/1998, http://dx.doi.org/10.1162/003355398555702.

Hall B., Murphy K., The Trouble with Stock Options, "Journal of Economic Perspectives", No. 17/2003, http://dx.doi.org/10.1257/089533003769204353.

Houston J., James Ch., CEO compensation and bank risk: is compensation in banking structured to promote risk taking, "Journal of Monetary Economics", No. 36/1995, http://dx.doi.org/10.1016/0304-3932(95)01219-2.

Jensen M., Murphy K., Remuneration: Where we've been, how we got to here, what are the problems, and how to fix them, ECGI Working Paper Series in Finance, 2004, http://dx.doi.org/10.2139/ssrn.561305.

Kaplan S., Executive Compensation and Corporate Governance in the U.S.: Perceptions, Facts and Challenges, mimeo, 2012.

Lewellen W., Executive Compensation in Large Industrial Companies, National Bureau of Economic Research, New York 1968. 
Murphy K., Executive Compensation: Where We Are, and How We Got There, [in:] G. Constantinides, M. Harris, R. Stulz (ed.), Handbook of the Economics of Finance, Elsevier Science North Holland 2012.

Murphy K., Zábojník J., CEO pay and appointments: a market-based explanation for recent trends, „American Economic Review”, No. 94(2)/2004, http://dx.doi. org/10.1257/0002828041302262.

OECD, Corporate Governance and the Financial Crisis: Key Findings and Main Messages, Paryż, 2009.

Philippon T., Reshef A., Wages and Human Capital in the U.S. Financial Industry: 1909-2006, NBER Working Paper, No. 14644/2009, http://dx.doi.org/10.1093/ qje/qjs030.

Słomka-Gołębiowska A., Uniform regulation of executive pay at banks: Will it make a difference? The case study of Poland, „International Journal of Disclosure and Governance", No. 10(2)/2013, http://dx.doi.org/10.1057/jdg.2013.4. 
